\title{
Intracellular gonadotropin-releasing hormone receptors in breast cancer and gonadotrope lineage cells
}

\author{
Kathleen R Sedgley*, Ann R Finch*, Christopher J Caunt and Craig A McArdle \\ Laboratories for Integrative Neuroscience and Endocrinology, University of Bristol, Dorothy Hodgkin Building, Whitson Street, Bristol BS1 3NY, UK \\ (Requests for offprints should be addressed to C A McArdle; Email: craig.mcardle@bris.ac.uk) \\ *(K R Sedgley and A R Finch contributed equally to this work)
}

\begin{abstract}
Gonadotropin-releasing hormone receptors (GnRHRs) are expressed in gonadotropes and several extra-pituitary sites. They are assumed to be cell surface proteins but the human (h) GnRHR lacks features favoring plasma membrane localization and receptor location varies with cell type. When expressed in mammary (MCF7) cells, cell surface hGnRHR binding was much lower than that of mouse and sheep GnRHRs (type I GnRHRs without C-terminal tails), Xenopus (X) and marmoset type II GnRHRs (type II GnRHRs with C-tails) or chimeric receptors (type I GnRHRs with added XGnRHR C-tails). hGnRHR binding was higher in $\alpha \mathrm{T} 4$ (gonadotrope-derived) cells and was increased less by C-tail addition. Whole cell levels of tagged human, Xenopus and chimeric GnRHRs were comparable (Western blotting) and confocal microscopy revealed that the hGnRHR is primarily intracellular
\end{abstract}

(distribution similar to the endoplasmic reticulum marker, calreticulin), whereas most XGnRHR is at the plasma membrane, and adding the $\mathrm{C}$-tail increased cell surface hGnRHR levels. A membrane-permeant antagonist increased cell surface hGnRHR number $\left(>4\right.$-fold, $t^{1} / 2=$ $4 \mathrm{~h}$ ) and also increased hGnRHR signaling and hGnRHRmediated inhibition of proliferation. A more rapid increase in hGnRHR binding occurred when the temperature was raised from 4 to $37^{\circ} \mathrm{C}$ ( $>5$-fold, $\left.t^{1} / 2=15 \mathrm{~min}\right)$ and this effect was prevented by mutation to prevent signaling. Thus, cell surface GnRHR expression depends on receptor and cell type and the hGnRHR is primarily an intracellular protein that traffics to the cell surface for signaling in MCF7 cells. Manipulations favoring such trafficking may facilitate selective targeting of extra-pituitary GnRHRs.

Journal of Endocrinology (2006) 191, 625-636

\section{Introduction}

Gonadotropin-releasing hormone ( $\mathrm{GnRH})$ stimulates gonadotropin secretion from the pituitary and thereby controls gametogenesis and steroidogenesis in the gonads (Stojilkovic \& Catt 1995, Millar et al. 2004). At the pituitary, GnRH binds 7 transmembrane region (7TM) receptors that act via $G_{\mathrm{q} / 11}$ to stimulate phospholipase $\mathrm{C}$. The consequent activation of protein kinase $\mathrm{C}$ and increase in the cytoplasmic $\mathrm{Ca}^{2+}$ concentration mediate GnRH effects on gonadotropin secretion and synthesis. GnRH-stimulated gonadotropin secretion can be blocked with antagonists, or mimicked by agonists, but in the latter case, sustained stimulation causes desensitization. Thus, both treatments ultimately reduce circulating gonadotropins and gonadal steroids in vivo, and this 'medical castration' underlies the use of GnRH analogs to treat steroid hormone-dependent neoplasms such as those of the prostate, ovary, endometrium or mammary gland (Schally 1999). In addition to expression in the pituitary, GnRH receptors (GnRHRs) are found (often along with GnRH) in many cancers of reproductive tissues (Cheng \& Leung 2005). Interest in these extra-pituitary GnRHRs stems primarily from the fact that GnRH analogs (or their cytotoxic derivatives) can inhibit proliferation of cell lines derived from such cancers, and that direct anti-proliferative effects may therefore contribute to the therapeutic effects of GnRH analogs in cancer treatment (Eidne et al. 1987, Kakar et al. 1994, Imai et al. 1997, Emons et al. 1998, Schally \& Nagy 1999, Limonta et al. 2003, Moretti et al. 2003, Cheng \& Leung 2005).

The 7TM receptors are typically located in the plasma membrane, where ligand binding causes activation of cognate G-proteins. On sustained or intense stimulation this is normally followed by receptor desensitization, internalization and downregulation, processes mediated by receptor phosphorylation and arrestin binding (Pierce \& Lefkowitz 2001, Shenoy \& Lefkowitz 2003). In contrast to our detailed knowledge of ligand-induced 7TM receptor trafficking, much less is known about the molecular determinants of receptor localization in the ligand naive state. In this state, the subcellular compartmentalization of 7TM receptors is dependent upon the efficiency with which nascent receptors are delivered to and retained at the plasma membrane, parameters that are dependent not only on receptor structure, but also on receptor number and cell type (Edwards et al. 2000, Tan et al. 2004). 
The cloned GnRHRs can be divided phylogentically into two distinct groups (Silver et al. 2005). Type I GnRHRs that mediate hypothalamic control of mammalian reproduction are preferentially activated by GnRH I. Remarkably, they lack C-terminal tails, structures that are present in all other 7TM receptors and are implicated in many aspects of receptor function (Bockaert et al. 2003). For many 7TM receptors, the agonist-induced phosphorylation that mediates arrestin binding (with consequent desensitization and internalization) occurs in the receptor's C-tail. However, type I GnRHRs are unique, in that where investigated, they do not bind arrestins or signal via arrestins, do not rapidly desensitize and are internalized slowly, apparently because they lack C-tails (Davidson et al. 1994, McArdle et al. 1995, 1996, 2002, Lin et al. 1998, Pawson et al. 1998, Vrecl et al. 1998, Blomenrohr et al. 1999, Willars et al. 1999, 2001, Heding et al. 2000, Hislop et al. 2000, 2001, Caunt et al. 2006). In contrast, type II GnRHRs (which include all non-mammalian GnRHRs) are preferentially activated by GnRH II and do have C-terminal tails. Where investigated, they bind arrestins, signal via arrestin (e.g. to ERK) and undergo rapid and arrestin-dependent internalization and desensitization (Davidson et al. 1994, McArdle et al. 1995, 1996, 2002, Lin et al. 1998, Pawson et al. 1998, Vrecl et al. 1998, Blomenrohr et al. 1999, Willars et al. 1999, 2001, Hislop et al. 2000, 2001, Caunt et al. 2006).

In addition to their roles in signaling, the C-tails of 7TM receptors can also influence receptor stability and it has been shown that addition of the catfish GnRHR C-tail to the rat GnRHR or addition of the Xenopus (X) GnRHR C-tail to the human or sheep GnRHRs increases cell surface receptor number (Lin et al. 1998, Heding et al. 2000, Finch et al. 2004, Caunt et al. 2006). The oligosaccharide side-chains of glycosylated receptors can also have major effects on expression by targeting the receptors to the plasma membrane. For example, the mouse (m)GnRHR has $\mathrm{N}$-linked glycosylation sites at Asn 4 and Asn18 within the amino-terminal sequence and is expressed at higher levels than the human (h)GnRHR (which has only the Asn18 site). hGnRHR expression can be increased by introducing a second glycosylation site (Asn4), just as mGnRHR expression can be reduced by removal of the Asn18 site (Davidson et al. 1995, 1996). More recently, the primate GnRHR-specific K191 residue has been shown to reduce cell surface GnRHR expression (Arora et al. 1999, Janovick et al. 2003) and the importance of trafficking to the plasma membrane has been illustrated by the discovery of a number of GnRHR point mutants that cause hypogonadotropic hypogonadism in humans. Although these were initially thought to impair ligand binding or effector coupling, it is now recognized that loss of receptor function actually reflects misrouting of otherwise functional receptors. Here, a key observation is that exposure to a membrane-permeant GnRHR antagonist (IN3) can facilitate signaling via several of these mutant hGnRHRs (Janovick et al. 2002, 2003, 2006, Brothers et al. 2004, Ulloa-Aguirre et al. 2004, Knollman et al. 2005). This antagonist apparently acts as a pharmacological chaperone, enabling the protein to fold appropriately into the conformation required for trafficking to the surface and thereby overcoming the inhibitory effect of the mutation. In this context, the quality control system of the endoplasmic reticulum (ER) may be particularly important, ensuring that inappropriately folded proteins do not escape the ER, or are targeted to proteosomes for degradation. It has recently been shown that over $60 \%$ of newly synthesized $\delta$-opioid receptor fails to traffic to the cell surface but is instead degraded in the proteasome and, in this model, membrane-permeant agonists and antagonists both increased wild-type receptor trafficking to the plasma membrane (Petaja-Repo et al. 2002). In the case of the GnRHR, IN3 also has a modest effect on the wild-type receptor leading to the suggestion that as much as $50 \%$ of the human GnRHR does not traffic to the plasma membrane in COS7 cells (Brothers et al. 2004).

In recent studies, we have used recombinant adenovirus (Ad) to express GnRHRs in hormone-dependent cancer cells that lack endogenous GnRHRs (as judged by radioligand binding and functional assays). In MCF7 breast cancer cells (for example), we find that transduction with Ad sheep (s)GnRHR causes expression of high affinity $G_{\mathrm{q}}$-coupled receptors that do not rapidly desensitize or internalize and mediate a potent antiproliferative effect of $\mathrm{GnRH}$ agonists that is dependent upon receptor number (Everest et al. 2001, Finch et al. 2004). In this model, antiproliferative effects mediated by the hGnRHR were consistently lower than those seen with the sGnRHR, presumably because the $\mathrm{hGnRH}$ was expressed at lower levels. In light of the data outlined above, we speculated that the hGnRHR may be inefficiently trafficked to and retained at the plasma membrane (as compared with other GnRHRs) and that these processes might differ for GnRHRs expressed in pituitary and extra-pituitary sites. To address these possibilities, we have generated recombinant Ad expressing epitopetagged human, Xenopus and chimeric GnRHRs and used these to explore receptor compartmentalization, trafficking and function. Here we show that the vast majority of hGnRHR expressed in unstimulated MCF7 cells is actually intracellular. Consequently, signaling is dependent upon ongoing trafficking of cryptic receptors to the cell surface and it may be possible to exploit this finding in therapies targeting extra-pituitary GnRHRs.

\section{Materials and Methods}

\section{Materials}

Peptides were from Sigma except for Buserelin and $\left[{ }^{125} \mathrm{I}\right]$ Buserelin ([T-BuSer ${ }^{6}$, Pro ${ }^{9} \mathrm{NH}$ ethylamide] GnRH-2000 Ci/mmol) that were provided by Prof. Sandow (Aventis Pharma GmbH, Frankfurt, Germany). [ $\left.{ }^{125} \mathrm{I}\right] \mathrm{GnRH}$ II (approximately $3400 \mathrm{Ci} / \mathrm{mmol}$ ) was prepared as described (Hislop et al. 2001). Myo- $\left[2-{ }^{3} \mathrm{H}\right]$ inositol $\quad(10-25 \mathrm{Ci} / \mathrm{mmol})$ and [methyl- $\left.{ }^{3} \mathrm{H}\right]$-thymidine were from Perkin-Elmer, (Boston, MA, 
USA). The membrane-permeant GnRHR antagonist, IN3 ((2S)-2-[5-[2-(2-axabicyclo[2.2.2] oct-2-yl)-1,1-dimethy-2oxoethyl]-2-(3,5-dimethylphenyl)-1H-indol-3-yl]-N-(2-pyridin-4-ylethyl)propan-1-amine) was provided by Dr Ashton Wallace (Merck and Co. Inc., Rahway, NJ, USA). Culture media and plasticware were from Gibco BRL and sera were from First Link (Brierly Hill, West Midlands, UK) and antibodies were from Invitrogen. cDNAs encoding wild-type GnRHRs were provided by Prof. R Millar (Medical Research Council Human Reproductive Sciences Unit, Edinburgh, UK).

\section{Engineering of receptors, cell culture and transfection}

Recombinant, E1-deleted Ad expressing mGnRHRs or mIIGnRHRs were made as described for the Ad sGnRHR, Ad hGnRHR and Ad XGnRHR and for chimeras consisting of the sGnRHR or hGnRHR with an added XGnRHR C-terminal tail (Ad s.XGnRHR and Ad h.XGnRHR) (Hislop et al. 2001, Finch et al. 2004). The hGnRHR and the h.XGnRHR were haemagglutinin (HA)-tagged as described for the XGnRHR (Caunt et al. 2004) and used to generate Ad as described (Caunt et al. 2006). A261K mutations in HA-tagged receptor vectors were generated using the Quick Change mutagenesis kit (Stratagene) and the primers 5'-GAA CAA TAT ACC AAG AAA ACG GCT GAA GAC TCT AAA AAT GAC GG- $3^{\prime}$ and $5^{\prime}$-CCG TCA TTT TTA GAG TCTTCA GCC GTT TTC TTG GTA TAT TGT TC-3' according to the manufacturer's instructions prior to sequence conformation and Ad generation as above (Anderson et al. 2000, Caunt et al. 2004). MCF7 cells from the European Collection of Cell Cultures (Salisbury, Wiltshire, UK) and $\alpha \mathrm{T} 4$ cells from Prof. P Mellon (University of San Diego, CA, USA) were cultured as described (Hislop et al. 2000, Finch et al. 2004). For experiments, cells were transferred to culture plates and infected the following day with Ad $(6 \mathrm{~h})$ before medium change. They were then cultured for $4-5$ days before use in $\left[{ }^{3} \mathrm{H}\right]$ thymidine incorporation assays or for 1 day for all other assays.

\section{Radioligand binding, $\left.{ }^{3} H\right]$ inositol phosphate $\left.\left(P^{3} H\right] I P_{\mathrm{x}}\right)$ accumulation and $\left.{ }^{\beta} \mathrm{H}\right]$ thymidine incorporation assays}

Radioligand binding to GnRHRs was measured in whole cell assays, with cells grown in 24-well plates (Hislop et al. 2001, Finch et al. 2004). Briefly, 50000 cells/well were incubated in physiological salt solution (PSS: $127 \mathrm{mM} \mathrm{NaCl}, 1.8 \mathrm{mM} \mathrm{CaCl}_{2}$, $5 \mathrm{mM} \mathrm{KCl}, 2 \mathrm{mM} \mathrm{MgCl} 2,0.5 \mathrm{mM} \mathrm{NaH} \mathrm{PO}_{4}, 5 \mathrm{mM}$ $\mathrm{NaHCO}_{3}, 10 \mathrm{mM}$ glucose, $0 \cdot 1 \%$ BSA and $10 \mathrm{mM}$ HEPES, $\mathrm{pH} 7 \cdot 4)$ containing $1-2.5 \times 10^{-10} \mathrm{M}\left[{ }^{125} \mathrm{I}\right]$ Buserelin or $\left.{ }^{[25} \mathrm{I}\right] \mathrm{GnRH}$ II and either 0 (total binding) or $10^{-6} \mathrm{M}$ (nonspecific binding) of the homologous competitor. Incubation times and temperatures are detailed in the figure legends and incubations were terminated by washing in ice-cold PSS before solubilization and quantification (Hislop et al. 2001, Finch et al. 2004). For comparison with earlier studies, the first binding experiments were performed using a 30-min incubation at $21^{\circ} \mathrm{C}$, conditions providing equilibrium binding to cell surface
GnRHRs without measurable internalization (McArdle et al. 1987, Hislop et al. 2000). Subsequent experiments were performed at 4 or $37^{\circ} \mathrm{C}$ in order to prevent or permit (respectively) receptor trafficking and function. For some experiments, receptor numbers (sites/cell) were calculated from the single-point binding data using published $K_{\mathrm{d}}$ estimates $\left(1 \cdot 4 \mathrm{nM}\right.$ for $\left[{ }^{125} \mathrm{I}\right]$ Buserelin binding to type I GnRHRs and $1 \cdot 4 \mathrm{nM}$ for $\left[{ }^{125} \mathrm{I}\right] \mathrm{GnRH}$ II binding to type II GnRHRs), the actual radioligand concentration, and assuming a Hill coefficient of 1 , as described (Finch et al. 2004). [ $\left.{ }^{3} \mathrm{H}\right] \mathrm{IP}_{x}$ accumulation was used as a measure of phospholipase $\mathrm{C}$ activity in cells labeled with $\left[{ }^{3} \mathrm{H}\right]$ inositol and stimulated in the presence of $10 \mathrm{mM}$ LiCl (Hislop et al. 2001, Caunt et al. 2004, Finch et al. 2004) using the stimuli detailed in the figure legends. $\left[{ }^{3} \mathrm{H}\right]$ Thymidine incorporation was used as a index of cell proliferation in cells grown in medium with $2 \%$ foetal calf serum (FCS), as described (Hislop et al. 2001, Finch et al. 2004) using the stimuli detailed in the figure legends.

\section{Western blotting}

Cells plated at 400000 cells $/ 60 \mathrm{mM}$ dish were lysed $16 \mathrm{~h}$ after infection and extracted for Western blotting as described (Hislop et al. 2001). Briefly, cells were washed in ice-cold PBS before being lysed for $30 \mathrm{~min}$ on ice in $200 \mu \mathrm{l}$ extraction buffer (10 mM Tris (pH 7.6), $1 \mathrm{mM}$ EDTA, $150 \mathrm{mM} \mathrm{NaCl}$, $25 \mathrm{mM} \mathrm{KCl}, 0 \cdot 1 \%$ Triton X-100, $1 \mathrm{mM}$ phenylmethylsulfonyl fluoride, $1 \mathrm{mM}$ dithiothreitol and Protease Inhibitor Cocktail Tablets (Roche)). After separation by SDS-PAGE $(10 \%$ gel $)$, the cells were transferred to polyvinylidene difluoride membrane and blocked with 5\% skimmed milk in Tris-buffered saline $(10 \mathrm{mM}$ Tris $(\mathrm{pH} 8 \cdot 0)$ in $150 \mathrm{mM}$ $\mathrm{NaCl}$ ) with $0 \cdot 1 \%$ Tween. The HA epitope was detected using mouse monoclonal anti-HA.11 (1:1000, clone 16B12, Cambridge Bioscience, Cambridge, UK) and visualized by enhanced chemiluminescence. Bands were scanned and quantified by densitometry (Image J, NIH, Bethesda, MA, USA) and HA-GnRHR expression was normalized to HA-hGnRHR expression in $\alpha \mathrm{T} 4$ cells.

\section{Confocal microscopy}

Cells were cultured and infected with Ad GnRHRs as described (Hislop et al. 2005). For cell surface staining, they were incubated for $1 \mathrm{~h}$ at $4{ }^{\circ} \mathrm{C}$ in DMEM with $1 \%$ BSA and mouse monoclonal anti-HA (1:200), washed with ice-cold PBS, fixed (30 min in $2 \%$ paraformaldehyde/PBS) then permeabilized (10 min in PBS $/ 0 \cdot 1 \%$ Triton X-100), washed $(3 \times)$, blocked $(1 \mathrm{~h}$ in PBS/0 $\cdot 1 \%$ Triton X-100/1\% BSA) and incubated $1 \mathrm{~h}$ with Alexa-Fluor 488 conjugated anti-mouse (1:500, in PBS/ $0 \cdot 1 \%$ Triton $\mathrm{X}-100 / 1 \% \mathrm{BSA})$. They were then washed with PBS $(2 \times)$, incubated with $2 \mu \mathrm{M}$ 4',6-diamidino-2-phenyindole (DAPI, $10 \mathrm{~min})$ and washed $(3 \times)$ before mounting in fluorescent mounting medium (DakoCytomation, Carpinteria, CA, USA). For whole cell staining, cells were washed with PBS, fixed, permeabilized and blocked as above before being exposed 
to anti-HA (as above) with or without rabbit polyclonal anti-calreticulin (1:200, Sigma). They were then washed in PBS ( $3 \times, 5 \mathrm{~min})$, incubated with Alexa Fluor 488 conjugated antimouse with or without Alexa Fluor 568 conjugated anti-rabbit (1:500) and DAPI, and mounted, as above. Cells were imaged using a Leica TCS-SP2 confocal laser scanning microscope attached to a Leica DM IRBE inverted epifluorescence microscope with a $63 \times$ HCX Apo BL 1:40 NA oil immersion objective and excitation using 450 and $488 \mathrm{~nm}$ laser lines. For internally controlled experiments, images were collected at identical photomultiplier settings and analyzed with Leica LCSLite software. Where confocal images were quantified, ImageJ software was used to determine fluorescence intensity (e.g. in plasma membrane or cytoplasm) by drawing around areas of interest. To avoid bias, this was performed by users unaware of the experimental treatments.

\section{Statistical analysis and data presentation}

The figures show the mean \pm s.E.M. of data pooled from $n$ independent experiments (raw data or data normalized as described in the figure legends) except for the Western blot and confocal microscopy images, which are representative of those obtained in at least three experiments. Statistical analysis was by Student's $t$-test (accepting $P<0 \cdot 05$ as statistically significant).

\section{Results}

Expression and distribution of GnRHRs in MCF7 and $\alpha T 4$ cells

We have recently used recombinant Ad to express GnRHRs in MCF7 breast cancer cells and explored the relationship between Ad titer and expression of human (h), sheep (s) and Xenopus (X) GnRHRs as well as chimeric receptors consisting of the entire hGnRHR or sGnRHR sequence with an added XGnRHR C-tail (h.XGnRHR and s.XGnRHR) (Finch et al. 2004). Here, we have extended this to include the mouse (m) GnRHR and the type II marmoset (mII) GnRHR measuring cell surface receptor number by radioligand binding to intact cells for $30 \mathrm{~min}$ at $21{ }^{\circ} \mathrm{C}$. In each case, maximal cell surface receptor numbers were achieved at $\mathrm{Ad}$ titers of 1 or $2 \times 10^{7} \mathrm{pfu} / \mathrm{ml}$ and these are illustrated in Fig. 1 . As shown, binding was barely detectable for the hGnRHR (approximately 2000 sites/cell) and was much lower than that seen for the other type I GnRHRs (approximately 30000 and 50000 sites/cell for the mGnRHR and the sGnRHR respectively). These values are similar to those estimated for endogenous GnRHRs of rat and sheep pituitaries or murine gonadotrope-derived cell lines (approximately 20 000-80 000 sites per gonadotrope (Everest et al. 2001)). The XGnRHR and $\mathrm{mIIGnRHR}$ were expressed at approximately 25000 and 110000 sites/cell (respectively) and addition of the XGnRHR C-tail increased binding of both type I GnRHRs (approximately 40000 and 400000 sites/cell for the h.XGnRHR and s.XGnRHR respectively).
We next generated Ad expressing HA-tagged hGnRHRs, XGnRHRs and h.XGnRHRs and found the receptors to be indistinguishable from wild-type receptors in functional and competition binding assays (not shown). The epitope-tagged receptors were then expressed in MCF7 cells and in $\alpha \mathrm{T} 4$ cells (gonadotrope progenitor cells that lack endogenous GnRHRs) prior to Western blotting. As shown (Fig. 2A), the HA-hGnRHR ran as two major bands of approximately 34 and $36 \mathrm{kDa}$ and fainter band of 60-70 kDa. With overexposed gels, a $32 \mathrm{kDa}$ band was also seen. These data are consistent with earlier studies showing that the non-glycosylated rat GnRHR shows anomalous electrophoretic mobility (running with an apparent size of $32 \mathrm{kDa}$ in spite of its actual molecular weight of approximately $38 \mathrm{kDa}$ ) and the existence of larger forms reflecting glycosylation and/or the presence of multimers (Neill et al. 1997). Similar bands were seen with the HA-h.XGnRHR, although addition of the C-tail shifted the smaller bands to higher apparent molecular weights (approximately 38 and $40 \mathrm{kDa}$ respectively) and these were accompanied by a more pronounced smeared band of 50-100 kDa in both cell types (Fig. 2A). The HA-XGnRHR also ran as two minor bands of approximately 40 and $42 \mathrm{kDa}$ in addition to a prominent broad band of 50-100 kDa. The HA-XGnRHR separation pattern is similar to that previously reported for the catfish GnRHR (Willars et al. 1999) and that seen with an HA-tagged mIIGnRHR (not shown). Parallel radioligand binding studies (Fig. 2C) revealed that the HA-hGnRHR was expressed at very low levels $(<0 \cdot 1 \mathrm{fmol} /$ well $)$ on the surface of MCF7 cells as compared with the HA-h.XGnRHR (approximately $2.4 \mathrm{fmol} /$ well) and the HA-XGnRHR (approximately $2 \cdot 6 \mathrm{fmol} /$ well), whereas Western blotting with whole cell proteins revealed relatively high levels of HA-hGnRHR in

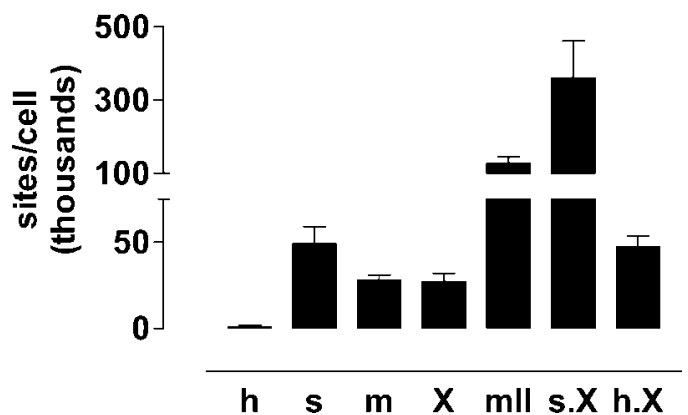

Figure $\mathbf{1}$ GnRHR binding in MCF7 cells: species comparison. MCF7 cells were infected with Ad expressing the human (h), sheep $(\mathrm{s})$, mouse $(\mathrm{m})$, Xenopus laevis $(\mathrm{X})$, marmoset type II (mII) receptors or chimeras with the C-tail of the XGnRHR added at the human or sheep GnRHRs (h.X and s.X respectively). They were then used in whole cell radioligand binding assays (incubation for $30 \mathrm{~min}$ at $21^{\circ} \mathrm{C}$ ) as described in Materials and Methods. The data are from a larger series in which Ad titer was varied and show maximal receptor number (e.g. that with Ad at $1-2 \times 10^{7} \mathrm{pfu} / \mathrm{ml}$ ). Receptor number was calculated from specific binding, assuming equilibrium binding to a single receptor class $\left(K_{\mathrm{d}}\right.$ values of $1.4 \mathrm{nM}$ for each receptor-cognate radioligand pair) and a Hill coefficient of 1. The data shown are pooled from ten experiments, each with triplicate observations (mean \pm S.E.M., $n=3-10$ ). 

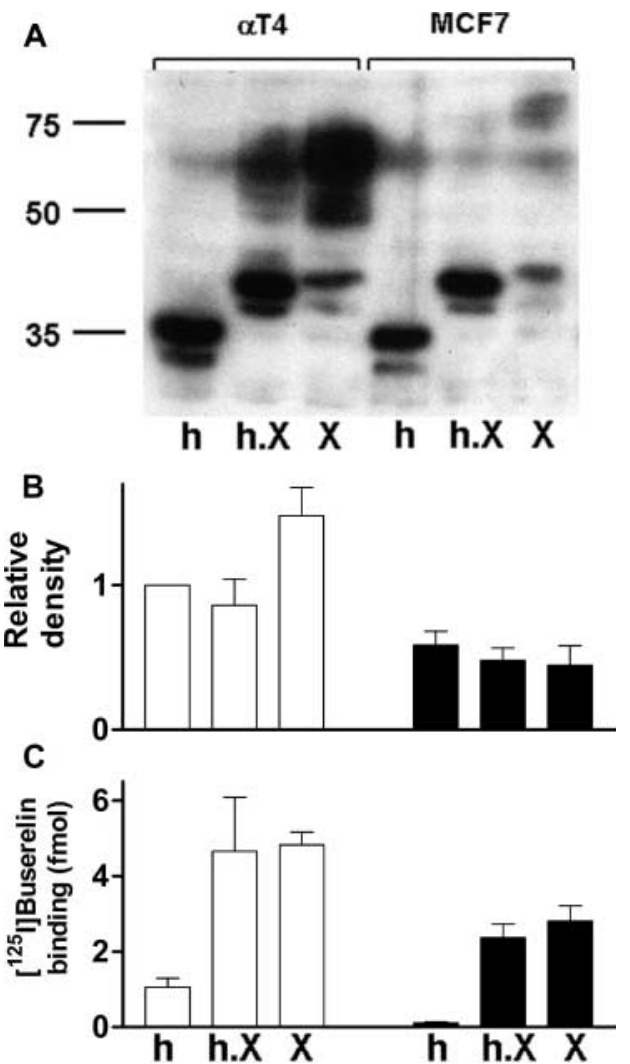

Figure 2 Western blotting and radioligand binding to HA-GnRHRs in MCF7 and $\alpha \mathrm{T} 4$ cells. $\alpha \mathrm{T} 4$ and MCF7 cells were infected with Ad HA-hGnRHR (h), Ad HA-h.XGnRHR (h.X) or Ad XGnRHR (X) at $1 X$ $10^{8} \mathrm{pfu} / \mathrm{ml}$ and used in flat plate binding assays (as described under Fig. 1) and Western blotting. (A) A representative Western blot, (B) Pooled data from three such blots (mean \pm s.E.M., $n=3$ ) quantified by densitometry and normalized to HA-hGnRHR expression in $\alpha \mathrm{T} 4$ cells (internal controls) and (C) Binding data pooled from four experiments (mean \pm S.E.M., $n=3-4$ ).

these cells (e.g. whole cell HA-hGnRHR, HA-h.XGnRHR and HA-XGnRHR levels were not significantly different, as judged by densitometry of the Western blot bands). Similar data were obtained in $\alpha \mathrm{T} 4$ cells except that cell surface expression of the HA-hGnRHR was higher (approximately $1 \mathrm{fmol} /$ well) so that the addition of the C-tail increased cell surface receptor number by $<5$-fold, as compared with $>20$-fold increase seen in MCF7 cells. Again, the higher cell surface expression of the HA-h.XGnRHR and HA-XGnRHR occurred in spite of comparable whole cell levels of all the three receptors in $\alpha \mathrm{T} 4$ cells. Although cell surface receptor binding was at least tenfold higher in $\alpha \mathrm{T} 4$ cells than in MCF7 cells (Fig. 2C), whole cell receptor expression was $<2$-fold higher (Fig. 2A and B) suggesting that a larger proportion of $h$ GnRHRs are membrane resident in $\alpha \mathrm{T} 4$ cells. When these proteins were probed with Alexa-Fluor 488-labeled antibody, little or no HA-hGnRHR was detected on the surface of either cell type as compared with clear cell surface staining of the HA-h.XGnRHR and HA-XGnRHR (Fig. 3). In contrast, strong staining was observed throughout the cytoplasm of permeabilized cells infected with Ad HA-hGnRHR and intracellular staining was largely restricted to a perinuclear compartment in $\mathrm{Ad}$ HA-XGnRHR-infected cells (Fig. 3). Staining for the tagged hGnRHRs and hXGnRHRs was similar to that of the endogenous ER marker, calreticulin, in MCF7 cells, and merging of images in dual-stained cells revealed a high degree of co-localization (Fig. 3).

\section{Influence of IN3 on GnRHR localization and function}

We next tested whether the membrane-permeant molecular chaperone, IN3, was able to increase cell surface receptor expression. Competition binding (not shown) revealed that IN3 has high affinity for hGnRHRs and h.XGnRHRs in MCF7 cells $\left(\log _{10}\right.$ molar $\mathrm{IC}_{50}$ values for competition with $\left[{ }^{125} \mathrm{I}\right]$ Buserelin were $-9 \cdot 1 \pm 0 \cdot 2$ and $-9 \cdot 4 \pm 0 \cdot 2$ respectively) and confocal microscopy revealed that IN3 increases cell surface HA-hGnRHR expression (Fig. 4). Indeed, $24 \mathrm{~h}$ with $1 \mu \mathrm{g} /$ ml IN3 increased plasma membrane HA-hGnRHR > 4-fold and this effect was both dose- $(50 \%$ effective concentration, $\left.\mathrm{EC}_{50}=0.003 \mu \mathrm{g} / \mathrm{ml}\right)$ and time-dependent $\left(t^{1} / 2=4 \mathrm{~h}\right)$ (Fig. 4). We also attempted to demonstrate the ability of IN3 to increase cell surface GnRHR number by radioligand binding but were unable to reliably wash IN3 pre-treatments from the cells (not shown). We therefore developed an indirect method based upon quantification of Buserelin-stimulated $\left[{ }^{3} \mathrm{H}\right] \mathrm{IP}_{x}$ accumulation in cells either co-incubated with IN3 or pre-incubated and co-incubated with IN3. As shown, IN3 inhibited Buserelinstimulated $\left[{ }^{3} \mathrm{H}\right] \mathrm{IP} \mathrm{P}_{x}$ accumulation, shifting the Buserelin doseresponse curve to the right as expected for a competitive antagonist (Fig. 5A). In contrast, when cells were pre-incubated for $24 \mathrm{~h}$ with the same concentrations of IN3 prior to stimulation with Buserelin (again in the presence of IN3), the inhibitory effect of the $1 \mu \mathrm{g} / \mathrm{ml}$ IN3 was reduced and the lower concentrations of IN3 actually increased maximal Buserelinstimulated $\left[{ }^{3} \mathrm{H}\right] \mathrm{IP}$ accumulation (Fig. 5B). The IN3 pretreatment effect is most evident from comparison of Buserelinstimulated $\left[{ }^{3} \mathrm{H}\right] \mathrm{IP}_{x}$ accumulation curves constructed with cells either co-incubated with a given concentration of IN3 or coand pre-incubated with the same IN3 concentration (e.g. compare open and filled symbols in Fig. 5C). Since these curves are constructed under conditions of identical proportional receptor occupancy, the difference between them reflects the increment in response due to increasing receptor number during the pre-incubation. This increase in $\left[{ }^{3} \mathrm{H}\right] \mathrm{IP}_{x}$ response caused by pre-treatment with IN 3 was paralleled by an increase in hGnRHR-mediated $\mathrm{Ca}^{2+}$ mobilization (not shown).

\section{$h \mathrm{GnRHR}$-mediated inhibition of proliferation}

Since the magnitude of GnRHR-mediated antiproliferative effects are dependent on receptor number (Finch et al. 2004) and maximal Buserelin-stimulated $\left[{ }^{3} \mathrm{H}\right] \mathrm{IP}_{x}$ accumulation was increased by IN3 pre-treatment (Fig. 5B), we suspected that this antagonist might actually increase the antiproliferative 
effect of hGnRHRs. To test this, control and Ad hGnRHRinfected MCF7 cells were cultured for 16-24 h with $0,0 \cdot 01$ or $0 \cdot 1 \mu \mathrm{g} / \mathrm{ml} \mathrm{IN3}$ and then for 4-6 days with or without $10^{-7} \mathrm{M}$ Buserelin (and the same concentration of IN3) prior
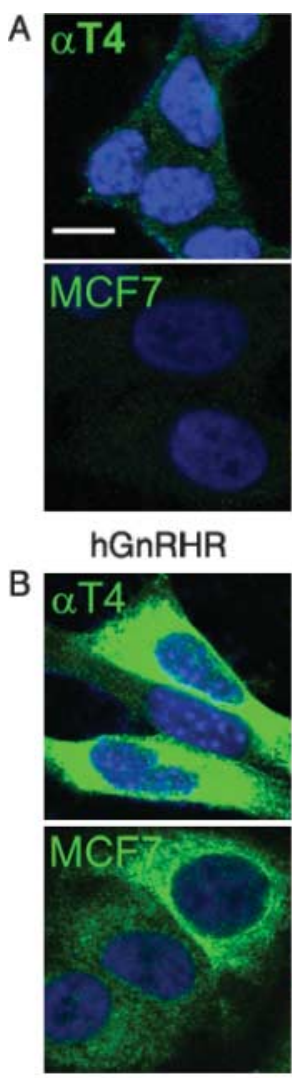

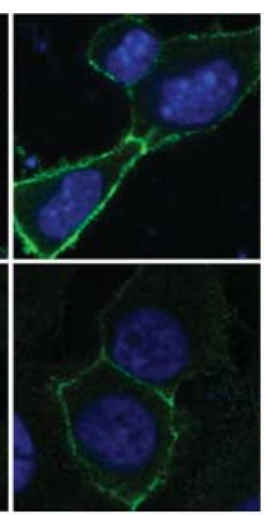

h.XGnRHR

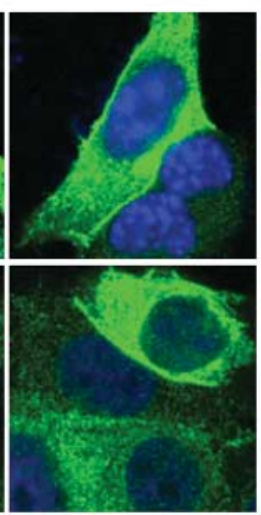

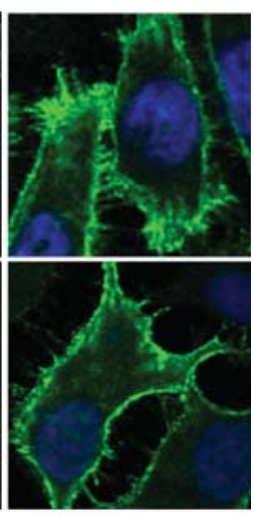

XGnRHR

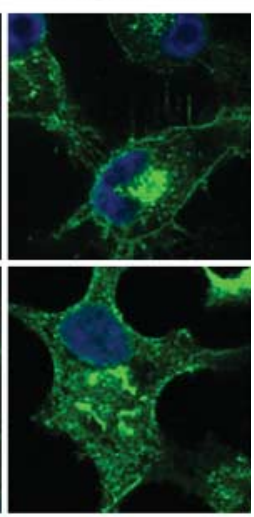

C
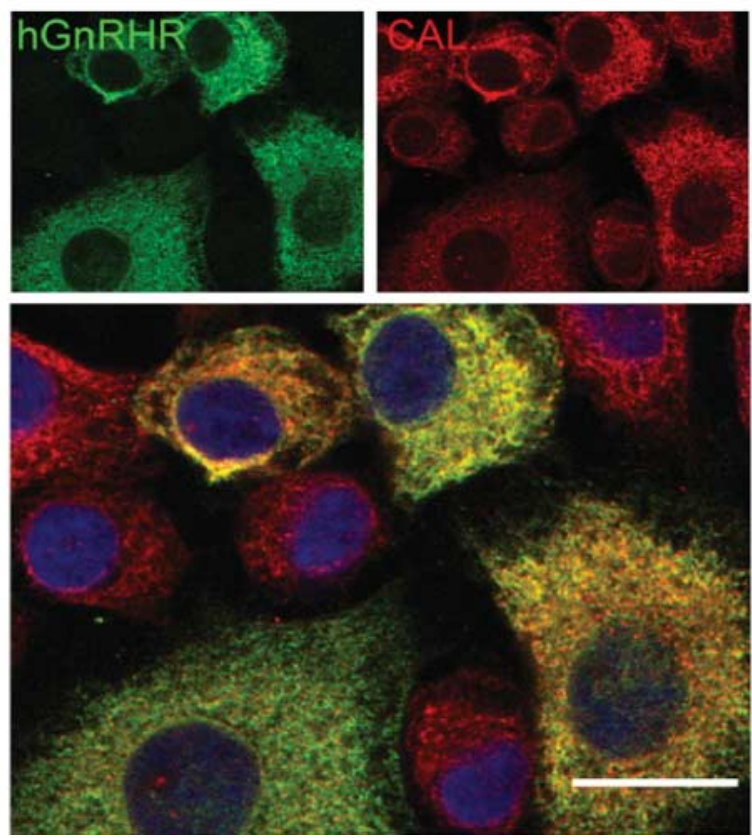

to assessment of $\left[{ }^{3} \mathrm{H}\right]$ thymidine incorporation. As expected, Buserelin had no measurable effect on $\left[{ }^{3} \mathrm{H}\right]$ thymidine incorporation in control cells but it had a clear inhibitory effect in cells infected with Ad hGnRHR (Fig. 6). IN3 had no measurable effect on $\left[{ }^{3} \mathrm{H}\right]$ thymidine incorporation in control cells without Ad hGnRHR or in Ad hGnRHR-infected cells in the absence of Buserelin (not shown). However, pretreatment with IN3 significantly increased the antiproliferative effect of Buserelin (e.g. in cells infected with $\mathrm{Ad}$ hGnRHR at $20 \mathrm{pfu} / \mathrm{nl}$, Buserelin reduced $\left[{ }^{3} \mathrm{H}\right]$ thymidine incorporation to approximately $40 \%$ of control without IN3 and to $20 \%$ of control with $0 \cdot 01$ or $0.1 \mu \mathrm{g} / \mathrm{ml} \mathrm{IN} 3$ ).

\section{Temperature-dependent trafficking of GnRHRs to the cell surface}

The observation that the hGnRHR mediates robust $\left[{ }^{3} \mathrm{H}\right] \mathrm{IP}_{x}$ accumulation in spite of the very low cell surface receptor number implies that hGnRHR signaling might be dependent upon ongoing trafficking of the receptor to the plasma membrane. To test this, we first monitored the receptormediated uptake of Alexa-Fluor 488-labeled anti-HA by confocal microscopy. In Ad hGnRHR-infected cells incubated for $60 \mathrm{~min}$ at $37^{\circ} \mathrm{C}$, the antibody accumulated in vesicles (presumably endosomes) whereas much less uptake was seen in control cells that had not been infected with Ad HA-hGnRHR (not shown). Thus, although very little of the HA-hGnRHR is resident at the plasma membrane (Figs 2 and 3), it clearly does pass through this compartment and should therefore have the potential to bind radioligand at a temperature permissive for trafficking. To test this, we examined the temperature dependence of binding and observed very little binding of $\left[{ }^{125} \mathrm{I}\right]$ Buserelin to $\mathrm{Ad}$ hGnRHR-infected MCF7 cells at $4{ }^{\circ} \mathrm{C}$, a temperature used to prevent trafficking of GnRHRs to or from the plasma membrane (Fig. 7). However, raising the temperature to $37^{\circ} \mathrm{C}$ (after $120 \mathrm{~min}$ at $4{ }^{\circ} \mathrm{C}$ ) caused a rapid increase in binding $\left(t^{1} / 2<15 \mathrm{~min}\right)$ to a maximum that was five- to tenfold greater than that in control cells remaining at $4{ }^{\circ} \mathrm{C}$. In contrast, in Ad h.XGnRHR-infected cells, considerable $\left[{ }^{125} \mathrm{I}\right]$ Buserelin binding was observed at $4{ }^{\circ} \mathrm{C}$ and increasing the temperature to $37^{\circ} \mathrm{C}$ caused only a modest (50\%) increase in binding (Fig. 7). The increase in binding seen on transferring Ad hGnRHR-infected cells from 4 to $37^{\circ} \mathrm{C}$ was retained when the cells were then returned to $4^{\circ} \mathrm{C}$ (not shown). These data are consistent with the existence of

Figure 3 Confocal imaging of HA-tagged GnRHRs in MCF7 and $\alpha \mathrm{T} 4$ cells. $\alpha \mathrm{T} 4$ and MCF7 cells on glass cover slips were infected with Ad HA-hGnRHR, Ad HA-h.XGnRHR or Ad XGnRHR $\left(10^{8} \mathrm{pfu} / \mathrm{ml}\right)$ and then used for confocal imaging of cell surface receptors $(A)$ or whole cell receptor expression (B) as described in Materials and Methods. Alternatively, MCF7 cells were infected with Ad HA-hGnRHR and permeabilized before staining for HA-hGnRHR (C, left image) and for endogenous calreticulin (C, right image). Co-localization of the two antigens is evident in the merged view (C, lower image). A bar $=10 \mu \mathrm{m}, \mathrm{C}$ bar $=20 \mu \mathrm{m}$. 


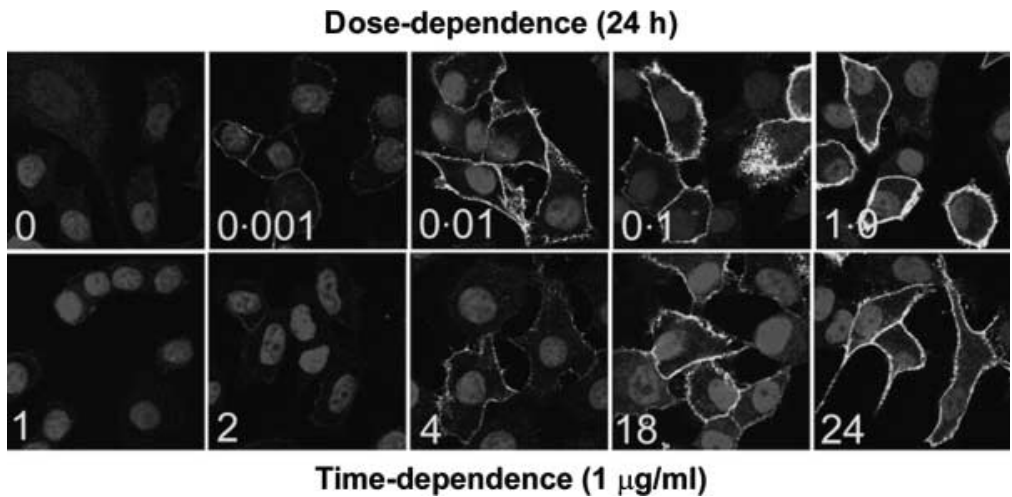

Figure 4 Effect of IN3 on cell surface expression of HA-hGnRHRs. MCF7 cells were infected with Ad HA-hGnRHR $\left(10^{8} \mathrm{pfu} / \mathrm{ml}\right)$ and cultured for $24 \mathrm{~h}$ in medium with 0 or $0 \cdot 001-1 \mu \mathrm{g} / \mathrm{ml}$ IN3 (upper panels) or for $0-24 \mathrm{~h}$ with $1 \mu \mathrm{g} / \mathrm{ml}$ IN3 (lower panels) as indicated. They were then used for confocal imaging of cell surface receptors as above (Fig. 3). IN3 effects on plasma membrane HA-hGnRHR expression were quantified using ImageJ software to define fluorescence intensity at the plasma membrane for each cell. These data were not corrected for background fluorescence and therefore provide accurate measures of potency $\left(\mathrm{EC}_{50} 0.003 \mu \mathrm{g} / \mathrm{ml}\right.$ at $24 \mathrm{~h}$ ) and kinetics (half-time approximately $4 \mathrm{~h}$ with $1 \mu \mathrm{g} / \mathrm{ml}$ IN3) but underestimate the fold increase caused by IN3 ( $>4$-fold increase with $1 \mu \mathrm{g} / \mathrm{ml}$ IN3 at $24 \mathrm{~h}$ ).

intracellular GnRHR pools that can traffic rapidly to the cell surface to bind ligand at $37^{\circ} \mathrm{C}$.

\section{Signal-dependent trafficking of GnRHRs to the cell surface}

To test the possible relevance of receptor signaling for this effect, we also determined the temperature dependence of binding to intact cells infected with Ad expressing the hGnRHR, h.XGnRHR and corresponding receptors with a mutation $(\mathrm{A} 261 \mathrm{~K})$ in the hGnRHR that prevents signaling to phospholipase C in COS-1 cells (Myburgh et al. 1998). In preliminary experiments, we found that the A261K mutation did not measurably alter cell surface receptor number, receptor affinity or ligand specificity for either the hGnRHR or the h.XGnRHR, and that these point-mutated receptors did not signal to phospholipase $\mathrm{C}$ (as judged by $\mathrm{Ca}^{2+}$ mobilization and $\left[{ }^{3} \mathrm{H}\right] \mathrm{IP}_{x}$ accumulation assays) in MCF7 cells (not shown). As expected, maximal binding to intact Ad hGnRHR- or Ad h.XGnRHR-infected cells was achieved after $1-3 \mathrm{~h}$ at $4{ }^{\circ} \mathrm{C}$ or $15-30 \mathrm{~min}$ at $37^{\circ} \mathrm{C}$ and the increment between maximal $37^{\circ} \mathrm{C}$ binding and maximal $4{ }^{\circ} \mathrm{C}$ binding was greater for the hGnRHR than for the h.XGnRHR (Fig. 8 upper panels). However, maximal $37^{\circ} \mathrm{C}$ binding did not exceed maximal $4{ }^{\circ} \mathrm{C}$ binding for either of the pointmutated receptors (Fig. 8 lower panel), implying that the temperature-dependent trafficking occurring during the incubation is dependent upon receptor signaling.

\section{Discussion}

Here we have explored the cellular compartmentalization of a number of wild-type and chimeric GnRHRs, and have observed remarkable differences in cell surface receptor numbers when recombinant Ad is used to express these receptors in MCF7 breast cancer and $\alpha \mathrm{T} 4$ gonadotrope lineage cells (Fig. 1). Notably, radioligand binding at $21^{\circ} \mathrm{C}$ in MCF7 cells revealed maximal expression levels of hGnRHRs to be approximately 2000 sites/cell, as compared with 5- to 20-fold higher levels of other type I and type II GnRHRs and 20- to 100-fold higher levels of chimeric receptors (human or sheep GnRHRs with added C-tails from XGnRHRs). These infections were performed with identically prepared E1deleted Ad in which GnRHR expression is driven by the cytomegalovirus promoter, and at Ad GnRHR titers of $1-2 \times 10^{7} \mathrm{pfu} / \mathrm{ml}$ (equivalent to a multiplicity of infection of $30-60)$ which results in transfection of over $90 \%$ of these cells (Everest et al. 2001). Accordingly, the differences in cell surface receptor number likely reflect differences in receptor structure, rather than differences in viral tropism, transfection efficiency or transcription rate. Similar differences were seen with HA-tagged hGnRHRs, HA-h.XGnRHRs and HAXGnRHRs (Fig. 2) but they do not correlate with independent measures of whole cell receptor expression (Figs 2 and 3). Indeed, densitometric analysis of Western blots revealed indistinguishable levels of all the three HA-tagged GnRHRs and confocal microscopy revealed abundant intracellular staining for HA-hGnRHR (whereas HAXGnRHR staining was predominantly in the plasma membrane). Thus, our data suggest that the hGnRHR is primarily an intracellular protein in MCF7 (breast cancer) and aT4 (gonadotrope lineage) cells.

Although little is known about the determinants of 7TM receptor compartmentalization in the ligand naive state, a number of linear motifs (e.g. tyrosine-based, dileucine, polyproline and FxxxFxxxF motifs) have been implicated in trafficking of 7TM receptors to the plasma membrane (Tan 
A
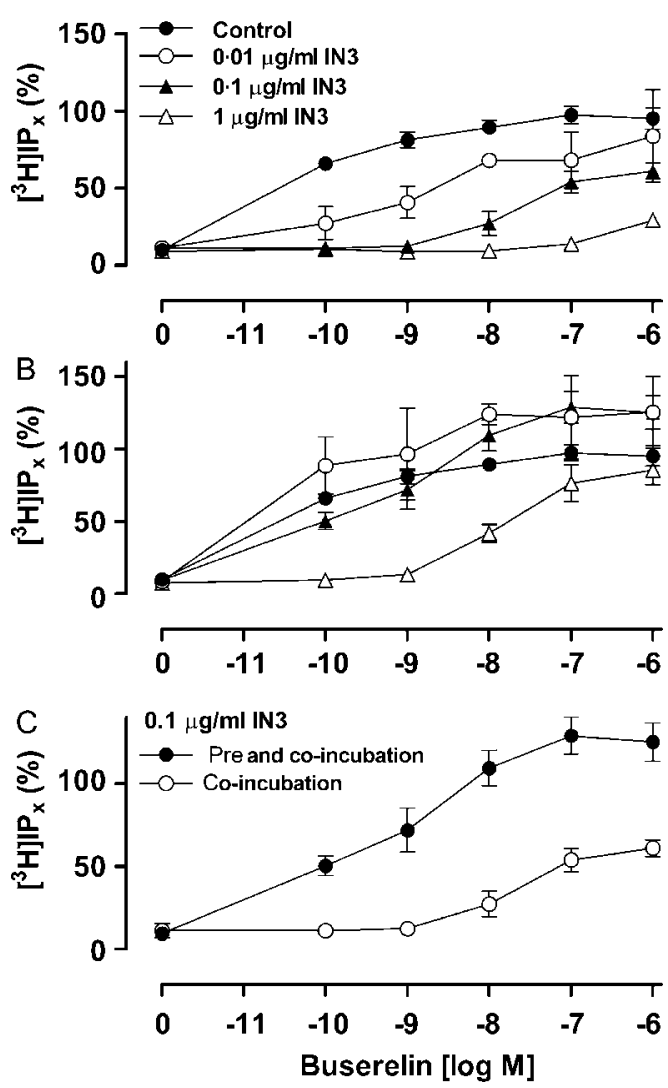

Figure 5 Effect of IN3 co- and pre-incubation on buserelinstimulated $\left[{ }^{3} \mathrm{H}\right] \mathrm{IP}_{X}$ accumulation. MCF7 cells were infected with Ad hGnRH-R $\left(2 \times 10^{7} \mathrm{pfu} / \mathrm{ml}\right)$ then transferred to media with either 0 or $0 \cdot 01-1 \mu \mathrm{g} / \mathrm{ml} \mathrm{IN} 3$ and $\left[{ }^{3} \mathrm{H}\right]$ inositol (for $16 \mathrm{~h}$ ), after which they were washed and stimulated for $1 \mathrm{~h}$ with 0 or $10^{-11}-10^{-6} \mathrm{M}$ Buserelin with $10 \mathrm{mM} \mathrm{LiCl}$ and either 0 (control) or $0 \cdot 01-1 \mu \mathrm{g} / \mathrm{ml}$ IN3. (A) shows data for cells stimulated with buserelin and IN3 (e.g. co-incubated) and (B) shows data from cells pre-treated with the indicated concentration of IN3 prior to stimulation with buserelin and the same IN3 concentration (pre- and co-incubated). The lower panel shows data extracted from the upper panels to simplify comparison of responses in cells either co-incubated or pre- and co-incubated with IN 3 at $0 \cdot 1 \mu \mathrm{g} / \mathrm{ml}$. The data shown are mean \pm S.E.M. $(n=3)$ from three experiments, each with triplicate observations and each normalized as a percentage of the maximal response in control cells (e.g. that seen with $10^{-7}$ or $10^{-6} \mathrm{M}$ Buserelin in control cells having no IN3).

et al. 2004) and many 7TM receptor binding proteins (e.g. chaperones, scaffolds and other 7TM receptors) can influence targeting to, retention at, or compartmentalization within, the plasma membrane (Edwards et al. 2000, Tan et al. 2004). To our knowledge, these motifs have not been implicated in GnRHR trafficking and accessory proteins or chaperones influencing compartmentalization of type I GnRHR have not been described. However, a primate-specific GnRHR residue (K191) has been identified that reduces plasma membrane expression of GnRHRs (Arora et al. 1999, Janovick et al. 2003) and cell surface GnRHR number can

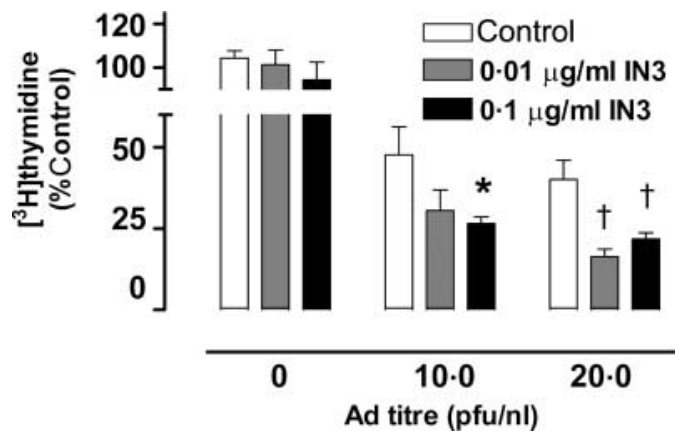

Figure 6 Effect of IN3 on hGnRHR-mediated inhibition of $\left[{ }^{3} \mathrm{H}\right]$ thymidine incorporation in MCF7 cells. Cells plated at a low density in 96-well plates were infected with Ad hGnRHR at 0, 10 or $20 \mathrm{pfu} / \mathrm{nl}$ then pre-incubated for $16-24 \mathrm{~h}$ with 0 or $0 \cdot 01-0 \cdot 1 \mu \mathrm{g} / \mathrm{ml}$ IN3 before stimulation for 4-6 days with 0 or $10^{-7} \mathrm{M}$ Buserelin and assessment of $\left[{ }^{3} \mathrm{H}\right]$ thymidine incorporation on the final day of culture. The figure shows data pooled from four separate experiments (mean \pm S.E.M., $n=3-4$ ), each of which had four to eight replicate observations. Pooling was achieved by normalizing the data as a percentage of $\left[{ }^{3} \mathrm{H}\right]$ thymidine incorporation seen in $\mathrm{Ad}$ titer matched control cells without peptide. IN3 had no measurable effect on $\left[{ }^{3} \mathrm{H}\right]$ thymidine incorporation in the absence of buserelin (not shown) but enhanced the antiproliferative effect of buserelin in Ad hGnRHR-infected cells. ${ }^{*} P<0 \cdot 05,{ }^{\dagger} P<0 \cdot 001$ compared with buserelin alone (control).

be influenced by glycosylation within the amino-terminal sequence (apparently because a second glycosylation site increases trafficking to the plasma membrane, above), and by the presence or absence of a C-terminal tail. Indeed, it is
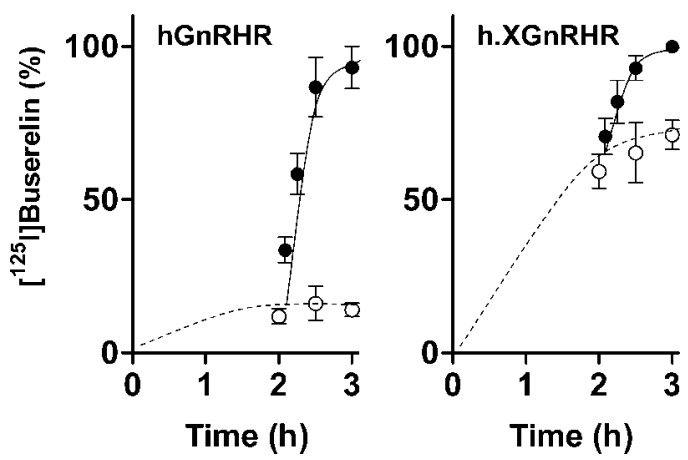

Figure 7 Temperature dependence of radioligand binding in MCF7 cells. MCF7 cells were infected with Ad hGnRHR and Ad h.XGnRHR $\left(1-2 \times 10^{7} \mathrm{pfu} / \mathrm{ml}\right)$ and used in flat plate binding assays as described in Materials and Methods using an initial incubation at $4^{\circ} \mathrm{C}$ for $120 \mathrm{~min}$. They were then either incubated for a further 30 or $60 \mathrm{~min}$ at $4{ }^{\circ} \mathrm{C}$ (open symbols), or were transferred to $37^{\circ} \mathrm{C}$ for a further 5-60 min (filled symbols), prior to termination by washing on ice. The data are specific binding pooled from three experiments each with duplicate or triplicate observations (mean \pm S.E.M., $n=3$ ). In order to pool data from multiple experiments, they were first normalized to the maximal binding (e.g. that observed after 30 or $60 \mathrm{~min}$ at $37^{\circ} \mathrm{C}$ ). These control values were $0.53 \pm 0.19$ and $3 \cdot 14 \pm$ $0.43 \mathrm{fmol} /$ well for the $\mathrm{hGnRHR}$ and h.XGnRHR respectively and the actual increments seen on raising the temperature from 4 to $37^{\circ} \mathrm{C}$ were approximately 0.5 and $1.5 \mathrm{fmol} /$ well for the hGnRHR and h.XGnRHR respectively. 

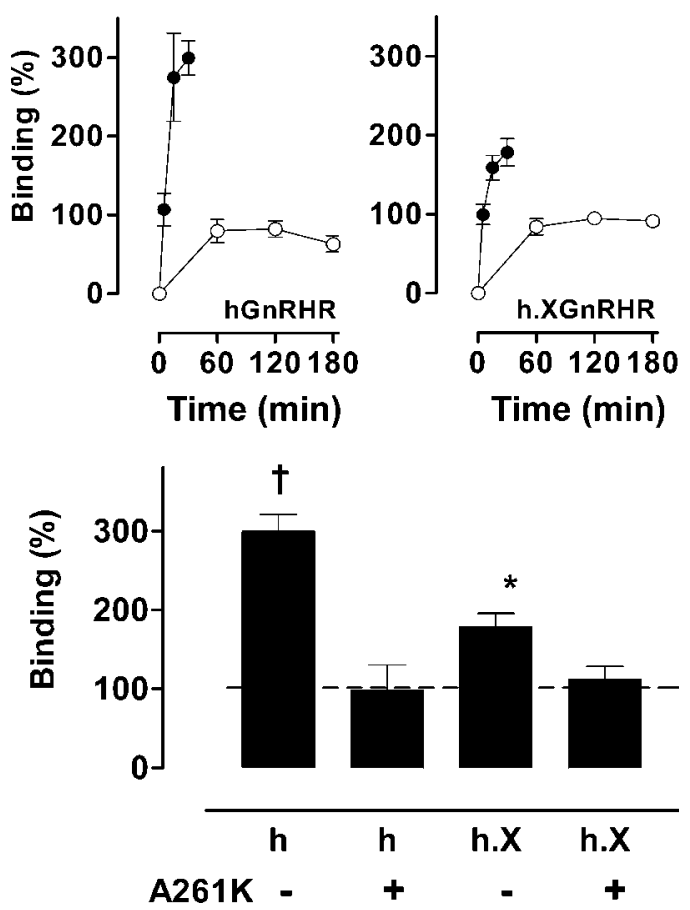

Figure 8 Temperature dependence of radioligand binding to wildtype, chimeric and point-mutated receptors in MCF7 cells. The upper panels show data from MCF7 cells infected with Ad hGnRHR or Ad h.XGnRHR $\left(1-2 \times 10^{7} \mathrm{pfu} / \mathrm{ml}\right)$ and used in flat plate binding assays as described in Materials and Methods using incubations that were entirely at 4 (open symbols) or $37^{\circ} \mathrm{C}$ (filled symbols). The data are specific binding pooled from four experiments each with duplicate or triplicate observations (mean \pm S.E.M., $n=3-4$ ) normalized to the maximal binding observed at $4{ }^{\circ} \mathrm{C}$ for each receptor. The lower panel shows data from similar experiments with cells infected with Ad hGnRHR or Ad h.XGnRHR as above (-) or with the A261 K mutation $(+)$. For each receptor, specific binding after $30 \mathrm{~min}$ at $37^{\circ} \mathrm{C}$ is normalized to maximal specific binding at $4{ }^{\circ} \mathrm{C}$ (indicated by the dashed line at $100 \%$ ). The data are pooled from four experiments each with duplicate or triplicate observations (mean \pm s.E.M., $n=3-$ 4). The $37^{\circ} \mathrm{C}$ binding was significantly greater than maximal $4{ }^{\circ} \mathrm{C}$ binding for the hGnRHR $\left({ }^{*} P<0 \cdot 01\right)$ and the h.XGnRHR $\left({ }^{\dagger} P<0 \cdot 05\right)$ but not for either of the point-mutated receptors.

thought that two cysteins within the C-tail of the catfish GnRHR provide a palmitoylation site used to generate a fourth intracellular loop that stabilizes the receptor at the cells surface (Blonrohr et al. 1999). Although the XGnRHR C-tail is not palmitoylated, it does have the potential for stabilization at the cell surface by an amphiphilic $\alpha$-helical section within the C-tail, as described for rhodopsin (Ballesteros et al. 2001, Caunt et al. 2004). Thus, it appears that the hGnRHR may be primarily intracellular in these cells because it lacks these structural features favoring trafficking to, and retention at, the cell surface. Interestingly, the Western blotting revealed distinct banding patterns for the receptors used herein. The HA-hGnRHR ran as two major bands of approximately 34 and $36 \mathrm{KDa}$ and similar bands were seen with the HA-h.XGnRHR, although these were shifted to higher apparent molecular weight by addition of the C-tail and an additional broad band of 50-100 KDa was also observed in both cell types (Fig. 2). The HA-XGnRHR ran predominantly as a broad band of 50-100 KDa. Since the predicted MWs of these receptors are all below $50 \mathrm{KDa}$, the high MW bands could reflect C-tail-dependent formation of SDSresistant multimers (including receptor oligomers) as reported for other G protein coupled receptors (GPCRs) (Carrillo et al. 2004).

Although we have not explored the intracellular localization in detail, the staining for tagged hGnRHRs and hXGnRHRs was similar to that of the ER marker, calreticulin. This is consistent with the possibility that a large proportion of the nascent hGnRHR fails to pass ER exit quality control checks and is therefore retained in the ER. We also found that the molecular chaperone, IN3, increased hGnRHR expression $>4$-fold (Fig. 4) and caused a parallel increase in signaling (Fig. 5) in MCF7 cells, confirming that the intracellular epitope is functional GnRHR and providing further evidence that inefficient ER exit contributes to the poor cell surface expression of hGnRHRs in MCF7 and $\alpha \mathrm{T} 4$ cells, as it does in HEK and COS cells (Janovick et al. 2003, Brothers et al. 2004, Ulluoa-Aguirre et al. 2004, Janovic et al. 2006). The finding that hGnRHRs are largely intracellular in gonadotrope lineage $\alpha \mathrm{T} 4$ cells is in apparent contradiction of early fractionation studies showing that pituitary GnRHRs are primarily located in the plasma membrane (Hopkins \& Gregory 1977, Marian \& Conn 1983, Zolman \& Theodoropoulos 1984, Badr \& Pelletier 1988). However, most of the earlier work was with rat and mouse GnRHRs, which lack the primate-specific K191 residue and have a second aminoterminal glycosylation site, features absent from the hGnRHR that favor plasma membrane expression. To our knowledge, the compartmentalization of human pituitary GnRHRs has not been defined in this way but subpopulations of intracellular GnRHRs have been reported in some models (Halmos \& Schally 2002) and immunohistochemical approaches have revealed cytoplasmic hGnRHRs in tissues including breast carcinomas (Moriya et al. 2001, Reich et al. 2005). Such observations have remained controversial, largely because of the lack of reliable and well-characterized GnRHR antibodies, but are entirely compatible with our data that hGnRHRs are predominantly intracellular in MCF7 breast cancer cells.

Although type I GnRHR transcripts detected in breast and ovarian cancers are identical to those of the pituitary, the receptors may differ functionally (Eidne et al. 1987, Kakar et al. 1994, Imai et al. 1997, Emons et al. 1998, Schally \& Nagy 1999, Limonta et al. 2003, Moretti et al. 2003, Cheng \& Leung 2005). Pituitary GnRHRs have high affinity for agonists such as Buserelin, whereas the vast majority of GnRHRs in extra-pituitary sites are low affinity and there are also apparent differences in signaling. Thus, it appears that the functional characteristics of the type I hGnRHR can vary according to the cell type in which it is expressed. Although the molecular determinants of such context-dependence are essentially unknown, one intriguing possibility is that this is 
related to the need for trafficking of intracellular receptors to the cell surface for signaling. In accord with this, the maximal cell surface hGnRHR number was tenfold lower in MCF7 cells than in $\alpha \mathrm{T} 4$ cells (Fig. 2) and addition of the XGnRHR C-tail increased receptor binding $>20$-fold in MCF7 cells as compared with $<5$-fold in $\alpha \mathrm{T} 4$ cells (Fig. 2). In addition to its major effect on expression of 'trafficking-deficient' point mutants (Janovick et al. 2002, 2003, 2006, Brothers et al. 2004, Ulloa-Aguirre et al. 2004, Knollman et al. 2005), IN3 caused a modest increase in cell surface expression of a hGnRHR-GFP fusion protein in COS7 cells, leading to the suggestion that as much as $50 \%$ of wild-type hGnRHRs are not transported to the cell surface in this model (Brothers et al. 2004). Our data suggest that the proportion of plasma membrane-resident hGnRHRs is much lower than this in MCF7 cells. We have also found that hGnRHR expression is extremely low $(<2000$ sites per cell) in Ad hGnRHRinfected Ishikawa endometrial cells as well as PC3 and LNCaP prostate cells (not shown), implying that cell surface hGnRHR expression may be particularly inefficient in hormone-dependent cancer cells. If so, this could underlie functional differences between GnRHRs in pituitary and extra-pituitary sites. Although the molecular determinants of cell-specific plasma membrane expression of hGnRHRs are unknown, we speculate that proteins facilitating such expression (e.g. molecular chaperones) could be relatively poorly expressed in cells other than gonadotropes. These data also raise the question of whether wild-type hGnRHR trafficking can be manipulated for therapeutic benefit. We have found that the $>2$-fold increase in cell surface hGnRHRs caused by $0 \cdot 1 \mu \mathrm{g} / \mathrm{ml}$ IN3 in MCF7 cells (Fig. 4), is associated with a two- to threefold increase in maximal hGnRHR-mediated $\left[{ }^{3} \mathrm{H}\right] \mathrm{IP}_{x}$ accumulation at matched proportional receptor occupancy (Fig. 5C), and an increase in hGnRHR-mediated inhibition of $\left[{ }^{3} \mathrm{H}\right]$ thymidine incorporation (Fig. 6). This enhancement of Buserelinmediated inhibition of proliferation by the membranepermeant antagonist is in contrast to the prevention of proliferation inhibition caused by antide and Cetrorelix (conventional membrane-impermeant antagonists) in this model (Everest et al. 2001). Thus, this membrane-permeant antagonist can, indeed, be used to enhance the antiproliferative effect of an agonist in this model.

The data outlined above are in accord with earlier work showing that cell surface expression of hGnRHRs is low compared with that of other GnRHRs because of relatively inefficient exit from the ER (as evidenced by the stimulatory effect of IN3) as well as inefficient retention at the cell surface (because it lacks the C-tail thought to increase cell surface receptor expression of type II GnRHRs by insertion into or association with the plasma membrane). However, we were puzzled by the observation that the hGnRHR-mediated robust stimulation of $\left[{ }^{3} \mathrm{H}\right] \mathrm{IP}_{x}$ accumulation in spite of the expression of $<2000$ sites per cell, and suspected that a proportion of the intracellular receptors might traffic to the cell surface for signaling during stimulation. In accord with this, we found that when Ad HA-hGnRHR-infected cells were incubated for $37^{\circ} \mathrm{C}$ with anti-HA, the antibody accumulated in punctate regions in the cytoplasm (not shown). This trafficking was also seen in experiments in which raising the temperature from 4 to $37^{\circ} \mathrm{C}$ increased hGnRHR binding > 5-fold but increased h.XGnRHR binding by only $50 \%$. Apparently, the intracellular hGnRHR must traffic to the surface for binding (at the permissive temperature), whereas the higher cell surface level of h.XGnRHR negates this requirement (Fig. 7). Moreover, the temperature-dependent trafficking of these receptors to the cell surface was prevented by introduction of a point mutation that prevents signaling to phospholipase $\mathrm{C}$, implying that a small pool of activated cell surface receptors may actually recruit receptors from the intracellular pool (Fig. 8). This temperature-dependent increase in hGnRHR binding does not simply reflect a temperature-dependent change in association or dissociation rate constants because the ligand binding pockets of the hGnRHR and h.XGnRHR are identical in spite of the fact that the pronounced ( $>5$-fold) increase in binding is only seen with the hGnRHR. Similarly, these differences in temperature dependence of binding do not reflect differences in receptor internalization because when assessed using a standard acid wash protocol (Hislop et al. 2001) internalization rates of the hGnRHR and h.XGnRHR were indistinguishable (data not shown, see also Finch et al. (2004) for similar experiments with the sGnRHR and s.XGnHR). Importantly, the effect of IN3 on cell surface receptor number (half-time approximately $4 \mathrm{~h}$ ) was much slower than the increase in binding (seen within 5 min of raising the temperature of MCF7 cells from 4 to $37^{\circ} \mathrm{C}$ ). This is presumably too fast to reflect accelerated exit from the ER and implies that an undefined proportion of the intracellular hGnRHRs is actually not ER-resident but instead, forms a receptor pool that can be rapidly trafficked to the plasma membrane to facilitate signaling. The mechanism by which these receptors are brought to the cell surface is unknown but no temperature-dependent increase was seen with the A261K mutants of the hGnRHR or the h.XGnRHR, implying that signaling via the small number of cell surface hGnRHRs may recruit cryptic intracellular hGnRHRs to the cell surface.

In summary, we have found that the hGnRHR is largely intracellular when expressed in MCF7 breast cancer and $\alpha \mathrm{T} 4$ gonadotrope lineage cells. Our data suggest that a large proportion of these receptors are retained in the ER so that cell surface expression can be increased by sustained treatment with IN3, a molecular chaperone that increases exit from the ER with a half-time of approximately $4 \mathrm{~h}$. In addition, we show that cell surface hGnRHR binding can be rapidly increased (half-time approximately $15 \mathrm{~min}$ ) by increasing temperature from 4 to $37^{\circ} \mathrm{C}$ in order to facilitate receptor trafficking. This raises the possibility that signaling is dependent upon rapid recruitment of hGnRHRs from a cryptic intracellular pool (which may well be distinct from the IN3-sensitive ER pool). We also suggest that the proportion 
of membrane-resident hGnRHRs may be particularly low in hormone-dependent cancers, in which case manipulations that increase receptor trafficking to the surface could be exploited to selectively enhance the effectiveness of therapies targeting extra-pituitary GnRHRs. Since membrane-permeant agonists can act as chaperones for other 7TM receptors, membrane-permeant GnRH agonists could be particularly effective stimuli for extra-pituitary GnRHRs.

\section{Acknowledgements}

We are grateful to Prof. R Millar (Medical Research Council Human Reproductive Sciences Unit, Edinburgh, UK) and to Dr Ashton Wallace (Merck and Co. Inc.) for materials. We also thank the MRC (UK) for an Infrastructure Award and Joint Research Equipment Initiative Grant to establish the Cell Imaging Facility at the University of Bristol, and M Jepson and A Leard for their assistance in its use.

\section{Funding}

This work was supported by the Wellcome Trust (Project Grant awards 062918 and 076557 to C A M). The authors declare that there are no conflicts of interest that would impair the partiality of this work.

\section{References}

Anderson RD, Haskell RE, Xia H, Roessler BJ \& Davidson BL 2000 A simple method for rapid generation of adenovirus vectors. Gene Therapy 7 1034-1038.

Arora KK, Chung HO \& Catt KJ 1999 Influence of a species-specific extracellular amino acid on expression and function of the human gonadotropin-releasing hormone receptor. Molecular Endocrinology 13 890-896.

Badr M \& Pelletier G 1988 High-resolution autoradiographic localization of LHRH receptors in the rat anterior-pituitary using fixed sections. Molecular and Cellular Endocrinology 58 257-261.

Ballesteros JA, Shi L \& Javitch JA 2001 Structural mimicry in G protein-coupled receptors: implications of the high-resolution structure of rhodopsin for structure-function analysis of rhodopsin-like receptors. Molecular Pharmacology $601-19$.

Blomenrohr M, Heding A, Sellar R, Leurs R, Bogerd J, Eidne KA \& Willars GB 1999 Pivotal role for the cytoplasmic carboxyl-terminal tail of a nonmammalian gonadotropin-releasing hormone receptor in cell surface expression, ligand binding, and receptor phosphorylation and internalization. Molecular Pharmacology 56 1229-1237.

Bockaert J, Marin P, Dumuis A \& Fagni L 2003 The 'magic tail' of G proteincoupled receptors: an anchorage for functional protein networks. FEBS Letters 546 65-72.

Brothers SP, Cornea A, Janovick JA \& Conn PM 2004 Human lossof-function gonadotropin-releasing hormone receptor mutants retain wildtype receptors in the endoplasmic reticulum: molecular basis of the dominant-negative effect. Molecular Endocrinology 18 1787-1797.

Carrillo JJ, Lopez-Giminez JF \& Milligan G 2004 Multiple interactions between transmembrane helices generate the oligomeric $\alpha 1 \mathrm{~b}$-adrenoreceptor. Molecular Pharmacology 66 1123-1137.
Caunt CJ, Hislop JN, Kelly E, Matharu AL, Green LD, Sedgley KR, Finch AR \& McArdle CA 2004 Regulation of gonadotropin-releasing hormone receptors by protein kinase $\mathrm{C}$ : inside out signalling and evidence for multiple active conformations. Endocrinology 145 3594-3602.

Caunt CJ, Finch AR, Sedgley KR, Oakely L, Luttrell LM \& McArdle CA 2006 Arrestin-mediated ERK activation by gonadotropin-releasing hormone receptors: receptor-specific activation mechanisms and compartmentalization. Journal of Biological Chemistry 281 2701-2710.

Cheng CK \& Leung PCK 2005 Molecular biology of gonadotropin-releasing hormone (GnRH)-I, GnRH-1I, and their receptors in humans. Endocrine Reviews 26 283-306.

Davidson JS, Wakefield IK \& Millar RP 1994 Absence of rapid desensitization of the mouse gonadotropin-releasing hormone receptor. Biochemical Journal 300 299-302.

Davidson JS, Flanagan CA, Zhou W, Becker II, Elario R, Emeran W, Sealfon SC \& Millar RP 1995 Identification of $N$-glycosylation sites in the gonadotropin-releasing hormone receptor: role in receptor expression but not ligand binding. Molecular and Cellular Endocrinology 107 241-245.

Davidson JS, Flanagan CA, Davies PD, Hapgood J, Myburgh D, Elario R, Millar RP, ForrestOwen W \& McArdle CA 1996 Incorporation of an additional glycosylation site enhances expression of functional human gonadotropin-releasing hormone receptor. Endocrine 4 207-212.

Edwards SW, Tan CM \& Limbird LE 2000 Localization of G-protein-coupled receptors in health and disease. Trends in Pharmacological Sciences 21 304-308.

Eidne KA, Flanagan CA, Harris NS \& Millar RP 1987 Gonadotropinreleasing-hormone $(\mathrm{GnRH})$-binding sites in human-breast cancer cell-lines and inhibitory effects of GnRH antagonists. Journal of Clinical Endocrinology and Metabolism 64 425-432.

Emons G, Muller V, Ortmann O \& Schulz KD 1998 Effects of LHRHanalogues on mitogenic signal transduction in cancer cells. Journal of Steroid Biochemistry and Molecular Biology 65 199-206.

Everest HM, Hislop JN, Harding T, Uney JB, Flynn A, Millar RP \& McArdle CA 2001 Signaling and antiproliferative effects mediated by GnRH receptors after expression in breast cancer cells using recombinant adenovirus. Endocrinology 142 4663-4672.

Finch AR, Green L, Hislop JN, Kelly E \& McArdle CA 2004 Signaling and antiproliferative effects of type I and II gonadotropin-releasing hormone receptors in breast cancer cells. Journal of Clinical Endocrinology and Metabolism 89 1823-1832.

Halmos G \& Schally AV 2002 Changes in subcellular distribution of pituitary receptors for luteinizing hormone-releasing hormone (LH-RH) after treatment with the LH-RH antagonist cetrorelix. PNAS 99 961-965.

Heding A, Vrecl M, Hanyaloglu AC, Sellar R, Taylor PL \& Eidne KA 2000 The rat gonadotropin-releasing hormone receptor internalizes via a beta-arrestin-independent, but dynamin-dependent, pathway: addition of a carboxyl-terminal tail confers beta-arrestin dependency. Endocrinology 141 299-306.

Hislop JN, Madziva MT, Everest HM, Harding T, Uney JB, Willars GB, Millar RP, Troskie BE, Davidson JS \& McArdle CA 2000 Desensitization and internalization of human and xenopus gonadotropin-releasing hormone receptors expressed in alphaT4 pituitary cells using recombinant adenovirus. Endocrinology 141 4564-4575.

Hislop JN, Everest HM, Flynn A, Harding T, Uney JB, Troskie BE, Millar RP \& McArdle CA 2001 Differential internalization of mammalian and nonmammalian gonadotropin-releasing hormone receptors. Uncoupling of dynamin-dependent internalization from mitogen-activated protein kinase signaling. Journal of Biological Chemistry 276 39685-39694.

Hislop JN, Caunt CJ, Sedgley KR, Kelly E, Mundell S, Green LD \& McArdle CA 2005 Internalization of gonadotropin-releasing hormone receptors (GnRHRs): does arrestin binding to the C-terminal tail target GnRHRs for dynamin-dependent internalization? Journal of Molecular Endocrinology 35 177-189.

Hopkins CR \& Gregory H 1977 Topographical localization of receptors for luteinizing-hormone-releasing hormone on surface of dissociated pituitary cells. Journal of Cell Biology 75 528-540. 
Imai A, Horibe S, Takagi A \& Tamaya T 1997 Gi protein activation of gonadotropin-releasing hormone-mediated protein dephosphorylation in human endometrial carcinoma. American Journal of Obstetrics and Gynecology 176 371-376.

Janovic JA, Knollman PE, Brothers SP, Ayala-Yanez R, Aziz AS \& Conn PM 2006 Regulation of G-protein coupled receptor trafficking by inefficient plasma membrane expression: molecular basis of an evolved strategy. Journal of Biological Chemistry 281 8417-8425.

Janovick JA, Maya-Nunez G \& Conn PM 2002 Rescue of hypogonadotropic hypogonadism-causing and manufactured $\mathrm{GnRH}$ receptor mutants by a specific protein-folding template: Misrouted proteins as a novel disease etiology and therapeutic target. Journal of Clinical Endocrinology and Metabolism 87 3255-3262.

Janovick JA, Ulloa-Aguirre A \& Conn PM 2003 Evolved regulation of gonadotropin-releasing hormone receptor cell surface expression. Endocrine 22 317-332.

Kakar SS, Grizzle WE \& Neill JD 1994 The nucleotide sequences of human GnRH receptors in breast and ovarian tumors are identical with that found in pituitary. Molecular and Cellular Endocrinology 106 145-149.

Knollman PE, Janovick JA, Brothers SP \& Conn PM 2005 Parallel regulation of membrane trafficking and dominant-negative effects by misrouted gonadotropin-releasing hormone receptor mutants. Journal of Biological Chemistry 280 24506-24514.

Limonta P, Moretti RM, Marelli MM \& Motta M 2003 The biology of gonadotropin hormone-releasing hormone: role in the control of tumor growth and progression in humans. Frontiers in Neuroendocrinology 24279 295.

Lin X, Janovick JA, Brothers S, Blomenrohr M, Bogerd J \& Conn PM 1998 Addition of catfish gonadotropin-releasing hormone $(\mathrm{GnRH})$ receptor intracellular carboxyl-terminal tail to rat $\mathrm{GnRH}$ receptor alters receptor expression and regulation. Molecular Endocrinology 12 161-171.

Marian J \& Conn PM 1983 Subcellular-localization of the receptor for gonadotropin-releasing hormone in pituitary and ovarian tissue. Endocrinology 112 104-112.

McArdle CA, Gorospe WC, Huckle WR \& Conn PM 1987 Homologous down-regulation of gonadotropin-releasing hormone receptors and desensitization of gonadotropes: lack of dependence on protein kinase C. Molecular Endocrinology 1 420-429.

McArdle CA, Forrest-Owen W, Willars G, Davidson J, Poch A \& Kratzmeier M 1995 Desensitization of gonadotropin-releasing hormone action in the gonadotrope-derived alpha T3-1 cell line. Endocrinology 136 4864-4871.

McArdle CA, Willars GB, Fowkes RC, Nahorski SR, Davidson JS \& ForrestOwen W 1996 Desensitization of gonadotropin-releasing hormone action in alphaT3-1 cells due to uncoupling of inositol 1,4,5-trisphosphate generation and $\mathrm{Ca}^{2+}$ mobilization. Journal of Biological Chemistry 271 23711-23717.

McArdle CA, Franklin J, Green L \& Hislop JN 2002 Signalling, cycling and desensitization of gonadotropin-releasing hormone receptors. Journal of Endocrinology 173 1-11.

Millar RP, Lu ZL, Pawson AJ, Flanagan CA, Morgan K \& Maudsley SR 2004 Gonadotropin-releasing hormone receptors. Endocrine Reviews 25 235-275.

Moretti RM, Marelli MM, van Groeninghen JC, Motta M \& Limonta P 2003 Inhibitory activity of luteinizing hormone-releasing hormone on tumor growth and progression. Endocrine-Related Cancer 10 161-167.

Moriya T, Suzuki T, Pilichowska M, Ariga N, Kimura N, Ouchi N, Nagura H \& Sasano H 2001 Immunohistochemical expression of gonadotropin releasing hormone receptor in human breast carcinoma. Pathology International 51 333-337.

Myburgh DB, Millar RP \& Hapgood JP 1998 Alanine-261 in intracellular loop III of the human gonadotropin-releasing hormone receptor is crucial for G-protein coupling and receptor internalization. Biochemical Journal 331 893-896.
Neill JD, Sellers JC, Musgrove LC \& Duck LW 1997 Epitope-tagged gonadotropin-releasing hormone receptors heterologously-expressed in mammalian (COS-1) and insect (Sf9) cells. Molecular and Cellular Endocrinology 127 143-154.

Pawson AJ, Katz A, Sun YM, Lopes J, Illing N, Millar RP \& Davidson JS 1998 Contrasting internalization kinetics of human and chicken gonadotropinreleasing hormone receptors mediated by C-terminal tail. Journal of Endocrinology 156 R9-R12.

Petaja-Repo UE, Hogue M, Bhalla S, Laperriere A, Morello JP \& Bouvier M 2002 Ligands act as pharmacological chaperones and increase the efficiency of delta opioid receptor maturation. EMBO Journal 21 1628-1637.

Pierce KL \& Lefkowitz RJ 2001 Classical and new roles of beta-arrestins in the regulation of G-protein-coupled receptors. Nature Reviews. Neuroscience $\mathbf{2}$ 727-733.

Reich O, Nogales FF \& Regauer S 2005 Gonadotropin-releasing hormone receptor expression in endometrial stromal sarcomas. Laboratory Investigation 85 200A-201A.

Schally AV 1999 LH-RH analogues: their impact on human reproduction and the control of tumorigenesis. Peptides 20 1247-1262.

Schally AV \& Nagy A 1999 Cancer chemotherapy based on targeting of cytotoxic peptide conjugates to their receptors on tumors. European Journal of Endocrinology 141 1-14.

Shenoy SK \& Lefkowitz RJ 2003 Multifaceted roles of beta-arrestins in the regulation of seven-membrane-spanning receptor trafficking and signalling. Biochemical Journal 375 503-515.

Silver MR, Nucci NV, Root AR, Reed KL \& Sower SA 2005 Cloning and characterization of a functional type II gonadotropin-releasing hormone receptor with a lengthy carboxy-terminal tail from an ancestral vertebrate, the sea lamprey. Endocrinology 146 3351-3361.

Stojilkovic SS \& Catt KJ 1995 Expression and signal transduction pathways of gonadotropin-releasing hormone receptors. Recent Progress in Hormone Research 50 161-205.

Tan CM, Brady AE, Nickols HH, Wang Q \& Limbird LE 2004 Membrane trafficking of $\mathrm{G}$ protein-coupled receptors. Annual Review of Pharmacology and Toxicology 44 559-609.

Ulloa-Aguirre A, Janovick JA, Brothers SP \& Conn PM 2004 Pharmacologic rescue of conformationally-defective proteins: implications for the treatment of human disease. Traffic 5 821-837.

Vrecl M, Anderson L, Hanyaloglu A, McGregor AM, Groarke AD, Milligan G, Taylor PL \& Eidne KA 1998 Agonist-induced endocytosis and recycling of the gonadotropin-releasing hormone receptor: effect of beta-arrestin on internalization kinetics. Molecular Endocrinology 12 1818-1829.

Willars GB, Heding A, Vrecl M, Sellar R, Blomenrohr M, Nahorski SR \& Eidne KA 1999 Lack of a C-terminal tail in the mammalian gonadotropinreleasing hormone receptor confers resistance to agonist-dependent phosphorylation and rapid desensitization. Journal of Biological Chemistry 274 30146-30153.

Willars GB, Royall JE, Nahorski SR, El Gehani F, Everest H \& McArdle CA 2001 Rapid down-regulation of the type I inositol 1,4,5-trisphosphate receptor and desensitization of gonadotropin-releasing hormone-mediated $\mathrm{Ca}^{2+}$ responses in alpha T3-1 gonadotropes. Journal of Biological Chemistry 276 3123-3129.

Zolman JC \& Theodoropoulos TJ 1984 Localization of putative gonadotropin-releasing hormone receptor protein in the anterior-pituitary. Cell Biochemistry and Function 2 208-212.

Received 18 July 2006

Accepted 19 September 2006

Made available online as an Accepted Preprint 25 September 2006 